\title{
Mechanism of antibacterial effect of plant based antimicrobials
}

\section{Nilgün Öncül, Şeniz Karabıyıklı}

\author{
Gaziosmanpaşa University, Faculty of Engineering and Natural Science, Food \\ Engineering Department, Tokat, Turkey
}

Keywords:

Organic

Acid

Phenolics

Antimicrobial

Effect

\section{Article history:}

Received 23.05.2016

Received in revised

form 28.07.2016

Accepted 01.09.2016

\section{Corresponding \\ author:}

Nilgün Öncül

E-mail:

nilgunoncul@

hotmail.com

\section{Abstract}

Introduction. In recent years, natural antimicrobials have gained popularity and food producers are trying to meet the new trends. For this purpose, plant based antimicrobials have been used for inhibiting or controlling the growth of microorganisms which cause food borne diseases or food spoilage.

Materials and methods. In this study, it was aimed to review the mechanisms of antimicrobial effects of plant based antimicrobials which were used in foods. The referenced literatures were obtained from bibliographic databases by searching through AGRICOLA, CAB Abstracts, EBSCO, FSTA, Global Health, Google Scholar, Index Copernicus, PubMed, Scopus, TUBITAK ULAKBIM Life Sciences Database, and Web of Science.

Results and discussion. Several fruit and vegetable juices, herbs and spices have been used as acidifying and flavoring agent for traditional meals, salads and appetizers. All these products themselves and also their extracts have been used extensively in food industry as plant based natural antimicrobials. These plant based additives have antimicrobial effects on microorganisms, mainly based on their organic acid composition and/or phenolic content. Organic acids and phenolics which are fundamental compounds in plants were mostly associated with the antimicrobial activity. However, the effect of antimicrobial component varies depending on the genotype or cell wall structure or initial population of the target microorganism, as well as the activity mechanism of the antimicrobial agent varies depending on the defecting way or binding zone in the cell. On the other hand, the inhibitory effect of plant based antimicrobials on different microorganisms were studied for several times. However, there is still a lack of understanding of their exact antimicrobial mechanism which cause the cidal or static effect. It is important to determine the mechanisms of antimicrobial action exactly to make it available, comprehensible and applicable for industrial applications.

Conclusion. Determining the exact mechanism of antimicrobial activity is important to make these antimicrobials available, comprehensible and applicable for the food industry. 


\section{Introduction}

The development Foodborne diseases are increasingly important public health issues all over the world, even in developed countries. On the other hand, spoilage of foods is still a critical point for the economy. In spite of modern techniques in the food industry, "food preservation" and "food safety" are still major problems [1-3]. While "food preservation" is a continuous fight against saprophyte microorganisms to extend the shelf life of foods [4], the "food safety" ensures to inhibit or to control the growth of pathogenic microorganisms [5]. Several conventional methods, such as: chilling, freezing, drying and heat treatment, as well as novel techniques such as: gamma irradiation, modified atmosphere packaging, high pressure and preservatives and/or additives have been used for food safety and food preservation [6,7]. However, some of these methods damage the organoleptic properties of foods. Synthetic/chemical preservatives especially have adverse effects on human health [2,7]. Therefore, the demands of the consumers focus on foods which are minimally processed and also fresh, preservative free, natural, safe and beneficial for health $[4,6,8]$. The regulatory agencies have restricted or permitted the usage levels of some currently accepted preservatives in foods and modified the legislations $[4,8]$. However, these regulations and modifications caused problems for food preservation and food safety in the food industry, and it made researchers look for natural and available alternatives which could replace the declined preservatives $[2,9,10]$. As a result, plant based antimicrobials have gained popularity as natural antimicrobial agents and the researchers focused on them. Application of natural antimicrobials has been outlined by regulatory agencies in the USA and the EU countries. Essential oils of cinnamon, clove, lemon grass and their active compounds (cinnamaldehyde, eugenol, citral) are generally recognized as safe (GRAS) due to Code of Federal Regulation 21 CFR part 182.20. Carvacrol, carvone, cinnamaldehyde, citral, p-ctmene, eugenol, limonene, menthol and thymol have been registered and recognized as safe-to-use in the EU countries [2,11-13].

\section{Food antimicrobials}

Antimicrobials are known as the substances that delay the growth of microorganisms or cause inhibition of them. When they show these functions in a food matrix, they are called "food antimicrobials" [7]. There are two main reasons for antimicrobial application in foods: the first one is ensuring food preservation and extending shelf-life by controlling the growth of saprophytic microorganisms whose metabolic end products or enzymes cause off-odors, off-flavors, textural problems and/or discoloration; and the second one is ensuring food safety by preventing the survival of pathogenic microorganisms which produce toxins $[7,13,14]$.

Food antimicrobials could be categorized as "natural antimicrobials" or "synthetic antimicrobials" based on their origins. Natural food antimicrobials could be obtained from various origins such as animals, microorganisms and plants [15]. The effects of animalorigin antimicrobials (lysozyme, lactoferrin, etc.), microbial-origin antimicrobials (nisin, reuterin, etc.) and plant-origin antimicrobials (thyme, lemon juice, etc.) against pathogenic and/or saprophytic microorganisms have been demonstrated in several studies $[15,16]$. The plant based antimicrobials are the most popular and useful group among the others because of low cost, availability and sounding familiar. 


\section{Plant based antimicrobials}

The plants themselves (leaves, stems, buds, flowers, fruits, seeds, bulbs and rhizomes) and some compounds held from plants (extracts, essential oils) have been used as plant based antimicrobials to ensure the food safety in the food industry [13,7]. In the studies on the antimicrobial effects of plants and their extracts, it was declared that plant based antimicrobials led to inhibition of many types of microorganisms such as Bacillus cereus, Bacillus coagulans, Bacillus megaterium, Bacillus subtilis, Bacteroides spp., Citrobacter spp., Clostridium spp., Corynebacteriumxerosis, Enterococcus feacalis, Escherichia coli, Escherichia coli O157:H7, Klebsiella pneumonia, Listeria monocytogenes, Micrococcus luteus, Porphyromonasspp., Pseudomonas aeruginosa, Staphlococcus aureus, Salmonella Typhimurium, Salmonella Paratyphi, Serratia spp., Shigella flexnerri and Yersinia enterocolitica [18-27].

Fresh juice, sauce and concentrate of fruits and vegetables (lemon, pomegranate, grape, unripe grape, mulberry, orange, sour orange, black carrot, garlic, onion, leek, red pepper, garden radish and horseradish), herbs and spices (allspice, bay leaf, cumin, coriander, fenugreek, oregano, rosemary, cloves, parsley, lemongrass, sage, ginger, vanilla) were studied to determine their antimicrobial effects on foodborne pathogens by several researchers [28-31]. Additionally, some essential oils were obtained from plants (cardamom, cloves, thyme, cumin, etc.) containing active components (carvacrol, terpene, eugenol, etc.), and some extracts (from sumac, cinnamon, cranberry, red cabbage, sour cherry pomace, etc.) extracted by water or ethanol were also investigated as plant based antimicrobials [2,4,13,16,32-35]. Laurus nobilis L. and Myrtus communis L. essential oils were tested against five Gram positive and four Gram negative bacteria including $L$. monocytogenes and E. coli. It was detected that the essential oils were effective on the testing pathogens, and the diameters of inhibition zones ranged between 7.2-37.7 $\mathrm{mm}$ [36]. Antimicrobial activity of Curcuma longa extracts against Klebsiella pneumoniae, Shigella flexneri, Candida albicans were determined and the diameters of the inhibition zone were measured as $6 \mathrm{~mm}, 12 \mathrm{~mm}$ and $13 \mathrm{~mm}$, respectively [37]. Antibacterial effect of pomegranate peel flour on six pathogens was studied and the minimum inhibitory concentration (MIC) values were between $20-50 \mathrm{mg} / \mathrm{mL}$ [38]. Allium sativum has antimicrobial effect against $E$. coli, B. subtilis, $S$. aureus, A. niger and $P$. chrysogenum and it caused inhibition zones ranged from $9 \mathrm{~mm}$ to $17 \mathrm{~mm}$ [39]. Antimicrobial effect of pomegranate juice was treated on seven bacteria and seven moulds. While, the maximum inhibitory effect was determined against $S$. aureus and $A$. niger, the minimum effect was determined against to $B$. subtilis and $T$. Reesei. The inhibition zones for all of the tested bacteria were measured between 15-26 mm, and they were between 10-19 $\mathrm{mm}$ for the tested moulds [26].

\section{Mechanism of antimicrobial effect}

Plant based antimicrobial agents have been used as natural preservatives in foods for a long while. Although, the antimicrobial effect against pathogenic and saprophytic microorganisms was studied several times, the exact mechanism of inhibition could not be defined clearly. The cell inhibition is expressed by perturbation of the membrane with phenolic compounds, interacting genetic material with coumarins, chelating metals with flavonoids and flavonols. For all that, inhibition may occur simultaneously as a result of different consecutive reactions. It was also observed that compounds which damage the cell 
membrane were affected by leakage of cell contents, disruption of metabolic enzymes and active transport, and loss of ATP $[1,7,40]$.

There are lots of remarks according to the results of studies on metabolic activity and effective component of antimicrobial agents that control or inhibit the target (pathogenic or saprophytic) microorganism. In these studies, it was summarized that the lethal effect was related to degradation of the cell wall, inhibition of the cytoplasmic membrane and proteins, coagulation of cytoplasm and depletion of proton motive force (PMF) [7,41].

The antimicrobial effect of a certain antimicrobial agent depends on three main factors: the psycho-chemical properties of the antimicrobial agent (dissociation constant of the acids, solubility, organoleptic properties and hydrophobicity/lipophilicity ratio), the environmental factors $(\mathrm{pH}$, water activity, temperature and structure of food), and the microbiological factors (initial and/or competitive microflora and type, genus, species and strain of the target microorganism) [2,5-7]. In addition, the antimicrobial effect of a plant based antimicrobial agent is mostly related with characteristic properties of the plant material such as genetic and environmental factors, part of the plant, methods of isolation, harvesting time and geographical location [4].

The microbial cells have complex metabolisms like prokaryote (bacteria) or eukaryote (yeasts and molds). So, an antimicrobial does not have a single site of action, it affects several systems in target microorganism [16]. Even if the plant based antimicrobials are obtained from different sources by different methods, the antimicrobial agent has three ways to inhibit a bacterial cell. These targets are destruction of the cell wall, inactivation of essential enzymes and damage of genetic material [16]. Plant based antimicrobials that are effective on microbial cells with different mechanisms are generally more effective on Gram-positive than Gram-negative bacteria. Gram-negative bacteria possess an outer membrane that surrounds the cell wall and protects diffusion of hydrophobic substances through its lipopolysaccharide covering $[4,13,42]$.

The specific characteristics of the food matrix are very important. The physical structure of the food may influence the antimicrobial activity due to the limitation of diffusion [2]. Effectiveness of some antimicrobials could be limited by the high amount of lipids, particularly with hydrophobic properties. In other words, hydrophobic antimicrobials cannot be solved in water and so they cannot be used for dipping/rinsing solutions [16]. Furthermore, the high amounts of lipid and/or protein in foods protect the bacteria against to damage of antimicrobials [2].

The chemical reaction among antimicrobials in foods with other food components such as lipids, proteins, carbohydrates and food additives can affect the antimicrobial activity. These reactions could decrease the antimicrobial activity as well as occurring the formation of off-flavors, -odor, and -colors. Besides this, many antimicrobials should be used at high concentrations to completely inhibit the spoilage causing and/or pathogenic microorganism. However, these amounts are not available for food processing because of unacceptable flavor, odor, or texture they caused in foods [43].

Organic acids and phenolics which are fundamental compounds in plants were mostly associated with the antimicrobial activity, and their mechanisms of antimicrobial activity were explained and clarified in most of studies $[13,44]$.

\section{Organic acids}

Organic acids have been used in the food industry as preservative agents for a long time due to their activity on survival and growth of microorganisms in foods. Organic acids change the concentration of hydrogen ions $(\mathrm{pH})$ in foods so they can control the microbial 
growth. Although, the optimum $\mathrm{pH}$ values for growing of bacteria are close to neutrality, they could tolerate the $\mathrm{pH}$ values between 4 and 9 [16]. Antimicrobial efficiency of the organic acids depends on type (acetic, benzoic, etc.) and concentration of the acid, environmental conditions ( $\mathrm{pH}$, temperature), and structure of the target microorganism [16]. However, the $\mathrm{pH}$ value is the most important factor among the others.

The strong or weak acid terms are used to describe the acids that donate a proton or dissociate in aqueous solutions [45]. Strong acids such hydrochloric or sulfuric acids which are fully dissociated, do not penetrate to the cell membrane and they exert their effectiveness by the denaturing the enzymes which on the surface of the cell. On the other side, the weak acids which are lipophilic, penetrate thorough into the cell membrane. Thus, the primary effect of weak acids is decreasing the $\mathrm{pH}$ value of cytoplasm [46]. Most of the acids in foods are weak acids such as lactic, acetic and citric acid, and they exist in a pHdependent equilibrium between the two states as fully dissociated or un-dissociated $[6,8]$. Organic acids have an optimal antimicrobial effect at a low $\mathrm{pH}$ values because they are in an un-dissociated state which can penetrate the cell membrane and reach to cytoplasm easily. The interior cell $\mathrm{pH}$ is neutral, so the acid is forced to dissociate into anions and protons $[47,48]$. The bacteria pump the accumulation of $\mathrm{H}^{+}$ions outside to the cell to protect the intracellular $\mathrm{pH}$. Hence the transportation membrane proteins and transport enzymes are denaturized in turn, the membrane permeability is increased [16]. Antimicrobial activity of organic acids mainly depend on disruption of membrane and cell signaling, accumulation of toxic anions, inhibition of glycolysis, active transport and essential metabolic reactions $[1,8,16]$. The antibacterial activity is $\mathrm{pH}$ dependent. It was assosiated with $\mathrm{pH}$ reduction of the substrate, depression of the intracellular $\mathrm{pH}$ or disruption of substrate transport by alteration of cell membrane permeability [50,51].

In conclusion, inactivation of microorganisms by using organic acids was attributed to disruption of membrane and cell signaling, accumulation of toxic anions, inhibition of glycolysis, inhibition of active transport and inhibition of essential metabolic reactions $[1,8,16]$.

\section{Phenolic compounds}

Phenolics are important compounds for the antimicrobial activity of plants and antimicrobial activity of plant phenolics has been intensively studied [34]. Phenolics may influence the growth and metabolism of bacteria. The inhibition of bacteria are included several mechanisms such as adsorption to cell membrane, destabilization of cytoplasmic membrane, permeabilization of plasma membrane, interaction with enzymes, substrate and metal ion deprivation, and inhibition of extracellular microbial enzymes[52,53].

The presence of the hydroxyl group in phenolic compounds plays an important role in antimicrobial activity [2]. The hydroxyl group reacts with the cell membrane and disrupts the structure of it, and the cell components are lost from the interior. This group promotes the delocalization of electrons which act as proton exchangers. Thus, it decreases in a gradient across the cytoplasmic membrane. When the gradient is reduced, PMF collapses and the ATP pool depletes. Eventually, it results in cell death. At the same time, -OH groups alter the cell metabolism by binding to the active site of enzymes [17]. The effects of phenolic compounds could vary depending on their concentration in foods. At low concentrations, the phenols impact the enzymes responsible for energy production, while at high concentrations, they raise the denaturation of proteins $[15,49]$.

As a result, inhibition mechanism of phenolic compounds can be explained by damaging the cytoplasmic membrane, collapsing the PMF, disruption of electron flow and 
depletion of active transport, thereby cell components become coagulated [2,4]. Phenolic compounds cause the leakage of macromolecules such as ribose and $\mathrm{Na}$ glutamate by altering the microbial cell membrane permeability. They could also interfere with membrane functions such as electron transport, nutrition, enzyme activity, protein and nucleic acid synthesis, and they interact with membrane proteins, causing disruption of the structures and functionality [15].

\section{Conclusion}

There has been an increasing demand of safe and natural food products. The food legislations have promoted the producers to use natural additives instead of synthetics. This drives the search of the researchers and food industry for alternative techniques to ensure food safety and preservation. In this context, natural food additives with a broad spectrum of antimicrobial activity are gaining popularity. Many studies in the literature have stated that several plants or plant derivatives are effective on inhibiting microorganisms which cause food spoilage or foodborne diseases. The antimicrobial effect of plant based antimicrobials is well documented; however, there is still a lack of understanding of their antimicrobial mechanisms of action. On the other hand, the explanation of the mechanisms of antimicrobial action should be available, comprehensible and applicable for industrial applications. While plant based antimicrobials can attain the desirable effects on foods, the inhibitory concentrations could be limited by undesirable organoleptic characteristics they cause. In the context of the "hurdle effect," antimicrobial effects of the plant based antimicrobials could be increased by the synergistic effects of other techniques, such as non-thermal processing, and the inhibitory concentrations could be decreased by this way. Moreover, specific regulations in food legislations are necessary for using plant based antimicrobials and labeling them.

\section{References}

1. Davidson P.M. (2001), "Chemical preservatives and naturally antimicrobial compounds", in M.P., Doyle, L.R., Beuchat and T.J. Montville (Eds.), Food microbiology fundamentals and frontiers, ASM Press. Washington DC, pp. 593-627.

2. Burt S. (2004), Essential oils: their antibacterial properties and potential applications in foods - a review, International Journal of Food Microbiology, 94, pp. 223- 253.

3. CDC (2014), 'Surveillance for Foodborne Disease Outbreaks', United States, 2012: Annual Report, Atlanta, Georgia: US Department of Health and Human Services, Centers for Disease Control and Prevention (CDC).

4. Rasooli I. (2007), Food preservation-a biopreservative approach, Food,1(2), pp. 111-136.

5. Juneja V.K., Dwivedi H.P., Yan X. (2012), Novel Natural Food Antimicrobials, Annual review of food science and technology, 3, pp. 381-403.

6. Lucera A., Costa C., Conte A., Del Nobile, M.A. (2012), Food applications of natural antimicrobial compounds. Frontiers in microbiology, 3, pp. 1-13.

7. Negi P.S. (2012), Plant extracts for the control of bacterial growth: efficacy, stability and safety issues for food application, International journal of food microbiology, 156(1), pp. $7-17$.

8. Brul S., Coote P. (1999), Preservative agents in foods: mode of action and microbial resistance mechanisms, International Journal of Food Microbiology, 50(1), pp. 1-17. 
9. Gould G.W. (2000). Preservation: past, present and future, British Medical Bulletin, 56(1), pp. 84-96.

10. Lopez A.S., Belloso O.M. (2008), Use of nisin and other bacteriocins for preservation of dairy products, International Dairy Journal, 18, pp. 329343.http://dx.doi.org/10.1016/j.idairyj.2007.11.009

11. Raybaudi-Massilia R.M., Rojas-Graü M.A., Mosqueda-Melgar J., Martin-Belloso O. (2008), Comparative study on essential oils incorporated into an alginate-based edible coating to assure the safety and quality of fresh-cut Fuji apples, Journal of Food Protection ${ }^{\circledR}, 71(6)$, pp. 1150-1161.

12. Turgis M., Han J., Caillet S., Lacroix M. (2009), Antimicrobial activity of mustard essential oil against Escherichia coli O157: H7 and Salmonella Typhi, Food Control, 20(12), pp. 1073-1079.

13. Tajkarimi M.M., Ibrahim S.A., Cliver D.O. (2010), Antimicrobial herb and spice compounds in food, Food control, 21(9), pp. 11991218.http://dx.doi.org/10.1016/j.foodcont.2010.02.003

14. Sultanbawa Y. (2011), Plant antimicrobials in food applications: Minireview. Science against microbial pathogens: communicating current research and technological advances, 1084-1092.

15. Tiwari B.K., Valdramidis V.P., O’Donnell C.P., Muthukumarappan K., Bourke P., Cullen P.J. (2009), Application of natural antimicrobials for food preservation, Journal of agricultural and food chemistry, 57(14), pp. 5987-6000.

16. Raybaudi-Massilia R.M., Mosqueda-Melgar J., Soliva-Fortuny R., Martin-Belloso,O. (2009), Control of pathogenic microorganisms in fresh-cut fruits and fruit juices by traditional and alternative natural antimicrobials, Comprehensive reviews in food science and food safety, 8, pp. 157-178.

17. Gyawali R., Ibrahim S.A. (2014), Natural products as antimicrobial agents, Food Control, 46, pp. 412-429.http://dx.doi.org/10.1016/j.foodcont.2014.05.047

18. Skandamis P.N., Nychas G.J.E. (2000), Development and evaluation of a model predicting the survival of Escherichia coli O157: H7 NCTC 12900 in homemade eggplant salad at various temperatures, $\mathrm{pHs}$, and oregano essential oil concentrations, Applied and Environmental Microbiology, 66(4), pp. 1646-1653.

19. Vrinda Menon K., Garg S.R. (2001), Inhibitory effect of clove oil on Listeria monocytogenes in meat and cheese, Food Microbiology, 18(6), pp. 647650.http://dx.doi.org/10.1006/fmic.2001.0430

20. Hsieh P.C., Mau J.L., Huang S.H. (2001), Antimicrobial effect of various combinations of plant extracts, Food Microbiology, 18(1), pp. 35-43.

21. Sengun I.Y., Karapinar M. (2005), Effectiveness of household natural sanitizers in the elimination of Salmonella typhimurium on rocket (Eruca sativa Miller) and spring onion (Allium cepa L.), International Journal of Food Microbiology, 98, pp. 319323.http://dx.doi.org/10.1016/j.ijfoodmicro.2004.07.011

22. Sengun I.Y., Karapinar M. (2005), Elimination of Yersinia enterocolitica on carrots (Daucus carota L.) by using household sanitisers, Food Control, 16, pp. 845-850.

23. Ferrante S., Guerrero S., Alzamora S.M. (2007), Combined use of ultrasound and natural antimicrobials to inactivate Listeria monocytogenes in orange juice, Journal of Food Protection ${ }^{\circledR}, 70$, pp. 1850-1856.

24. Aibinu I., Adenipekun T., Adelowotan T., Ogunsanya T., Odugbemi T. (2007), Evaluation of the antimicrobial properties of different parts of Citrus aurantifolia (lime fruit) as used locally, African Journal of Traditional, Complementary, and Alternative Medicines, 4(2), pp. 185-190. 
25. Duman A.D., Ozgen M., Dayisoylu K., Erbil S.N., Durgac C. (2009), Antimicrobial Activity of Six Pomegranate (Punica granatum L.) Varieties and Their Relation to Some of Their Pomological and Phytonutrient Characteristics, Molecules, 14, pp. 1808-1817.

26. Dahham S.S., Ali M.N., Tabassum H., Khan M. (2010), Studies on Antibacterial and Antifungal Activity of Pomegranate (Punica granatum L.), American-Eurasian Journal of Agricultural \& Environmental Sciences, 9(3), pp. 273-281.

27. Karabıyıklı Ş., Kışla D. (2012), Inhibitory effect of sour pomegranate sauces on some green vegetables and kisir,155(3), pp. 211-216.

28. Değirmenci H., Karapınar M., Karabıyıklı Ş. (2012), The survival of E. coli O157:H7, S. Typhimurium and L. monocytogenes in black carrot (Daucus carota) juice, International Journal of Food Microbiology, 153, pp. 212-215.

29. Karabıyıklı Ş., Değirmenci H., Karapınar M. (2012), The survival of Escherichia coli O157:H7 and Salmonella Typhimurium in black mulberry (Morus nigra) juice, African Journal of Microbiology Research, 6(48), pp. 7464-7470.

30. Karabıyıklı, Ş., Değirmenci, H., Karapınar, M. (2014), Inhibitory effect of sour orange (citrus aurantium) juice on $S$. Typhimurium and L. monocytogenes, LWT-Food Science and Technology, 55(2), pp. 421-425.

31. Öncül N., Karabıyıklı Ş. (2015), "Bitkisel Kaynaklı Antimikrobiyallerin Gıdalarda Bulunan Mikroorganizmalar Üzerindeki İnhibitif Etkinliği" [Inhibitory effect of plant based antimicrobials on the microorganisms in foods], Akademik Gida [Academic Food Journal], 13(2), pp. 63-70.

32. Quattara B., Simard R.E., Holley R.A., Piette G.J.P., Begin A. (1997), Antibacterial activity of selected fatty acids and essential oils against six meat spoilage organisms, International journal of food microbiology, 37, pp. 155-162.

33. Kıvanc M., Kunduhoğlu B. (1997), Antimicrobial activity of fresh plant juice on the growth of bacteria and yeasts, Journal of Osmangazi University, 1(1), pp. 27-35.

34. Dorman H.J.D., Deans S.G. (2000), Antimicrobial agents from plants: antibacterial activity of plant volatile oils, Journal of applied microbiology, 88(2), pp. 308-316.

35. Demirdöven A., Karabıyıklı Ş., Tokatlı K., Öncül N. (2015), Inhibitory effects of red cabbage and sour cherry pomace anthocyanin extracts on food borne pathogens and their antioxidant properties, LWT - Food Science and Technology, 63, 8-13.

36. Cherrat L., Espina L., Bakkali M., García - Gonzalo D., Pagán R., Laglaoui A. (2014), Chemical composition and antioxidant properties of Laurus nobilis L. and Myrtus communis $L$. essential oils from Morocco and evaluation of their antimicrobial activity acting alone or in combined processes for food preservation, Journal of the Science of Food and Agriculture, 94(6), pp. 1197-1204.

37. Rao N., Mittal S. (2014), An in vitro evaluation of the antimicrobial activity of curcuma longa against selected pathogenic microorganisms, Research Journal of Science and Technology, 6(2), pp. 71.

38. Gullon B., Pintado M.E., Pérez-Álvarez J.A., Viuda-Martos M. (2016), Assessment of polyphenolic profile and antibacterial activity of pomegranate peel (Punica granatum) flour obtained from co-product of juice extraction, Food Control, 59, pp. 94-98.

39. Jadon R., Dixit S. (2014), Phytochemical extraction and antimicrobial activity of some medicinal plants on different microbial strains, Journal of Medicinal Plants Studies, 2(3), pp. 58-63.

40. Cowan M.M. (1999), Plant products as antimicrobial agents, Clinical microbiology reviews, 12(4), pp. 564-582.

41. Kalembra D., Kunicka A. (2003), Antibacterial and antifugal properties of essential oils, Current medicinal chemistry, 10, pp. 813-829.

42. Marija R., Pavle S., Dean J., Ljupco A., Sandra M., Mirko P. (2012), Antimicrobial activity of plant extracts on some food borne pathogenic and saprophytic bacteria, Days of 
Veterinary Medicine, 3rd International Scientific Meeting 2-4 September 2012, Ohrid, Macedonia, pp.176-178.

43. Davidson P.M., Branen, A.L. (2005), "Food antimicrobials - an introduction" in P.M., Davidson, S.N., Sofos and A.L., Branen (Eds.), Antimicrobials in foods, CRC Press., Newyork, NY, pp. 1-10.

44. Parish M.E., Beuchat L.R., Suslow T.V., Harris L.J., Garrett E.H., Farber J.N., Busta F.F. (2003), Methods to reduce/eliminate pathogens from fresh and fresh-cut produce, Comprehensive Reviews in Food Science and Food Safety, 1(2), pp. 161-173..

45. Doores S. (2005), "Organic acids", in P.M. Davidson, S.N., Sofos and A.L., Branen (Eds.), Antimicrobials in foods, CRC Press, Newyork, NY, pp. 93-127.

46. Rahman M.S. (2007), "pH in food preservation", in M. S., Rahman (Ed.), Handbook of food preservation, CRC Press, Newyork, NY, pp. 287-296.

47. Davidson P.M., Harrison M.A. (2002), Resistance and adaptation to food antimicrobials, sanitizers, and other process controls, Food technology-champign then chicago, 56(11), pp. $69-78$.

48. Ricke S.C. (2003), Perspectives on the use of organic acids and short chain fatty acids as antimicrobials, Poultry science, 82(4), pp. 632-639.

49. Lopez-Malo Vigil A., Palou E., Alzamora S.M. (2005), "Naturally occuring compoundsplant sources", in P.M. Davidson, S.N., Sofos and A.L., Branen (Eds.), Antimicrobials in foods, CRC Press, Newyork, NY, pp. 429-446.

50. Ikawa F. (1995), " Organic acids in food preservation", in K. Uezawa (Ed.), Natural compound in food preservation, Ochanomizu Kikaku, Tokyo, pp. 134-181.

51. Ewadh M., Hasan H., Bnyan I., Mousa F., Sultan J., Ewadh M. (2013), Antibacterial activity of 2- (2-Hydroxy phenylimino) acetic acid, Advances in Life Science and Technology, 7, pp. 15-19.

52. Heinonen M. (2007), Antioxidant activity and antimicrobial effect of berry phenolics - a Finnish perspective, Molecular Nutrition \& Food Research, 51, pp. 684-691.

53. Rodr1'guez Vaquero M.J., Alberto M.R., Manca de Nadra M.C. (2007), Antibacterial effect of phenolic compounds from different wines, Food Control, 18, pp. 93-101. 